\title{
Gambaran Klinis Diare pada Pasien Anak Leukemia Limfoblastik Akut dengan Kemoterapi
}

\author{
${ }^{1}$ Gregorius F. Anver \\ ${ }^{2}$ Max F.J. Mantik \\ ${ }^{2}$ Jeanette I. Ch. Manopo
}

\author{
${ }^{1}$ Kandidat Skripsi Fakultas Kedokteran Universitas Sam Ratulangi Manado \\ ${ }^{2}$ Bagian Pediatri Fakultas Kedokteran Universitas Sam Ratulangi Manado \\ E-mail:greganver02@gmail.com
}

\begin{abstract}
Chemotherapy is usually used in acute lymphoblastic leukemia (ALL) patients to kill the neoplasmic cells. Albeit, this chemotherapy also destroys normal cells in the body. One of the complications of chemotherapy is destruction of digestive mucous cells that results in diarrhea. Diarrhea can cause dehydration, hypokalemia, acidosis that could lead to shock as well as death. This study was aimed to obtain the clinical profile of diarrhea in children with ALL treated with chemotherapy. This was a descriptive retrospective study with a cross sectional design using 60 medical records of children with ALL treated with chemotherapy and suffered from diarrhea in Estella room at Pediatrics Department Prof. Dr. R. D. Kandou Hospital in 2011-2015. Conclusion: In this study, there were only a fiew ALL patients treated with chemotherapy that got diarrhea. Diarrhea associated with blood and vomiting was very minimal meanwhile diarrhea associated with fever occured in some cases.
\end{abstract}

Keywords: acute lynphoblastic leukemia, chemotherapy diarrhea

\begin{abstract}
Abstrak: Kemoterapi merupakan salah satu metode pengobatan yang sering digunakan pada penderita leukemia limfoblastik akut (LLA) untuk membunuh sel neoplasma. Dilain pihak kemoterapi tidak hanya membuhuh sel-sel leukemia tetapi juga menyerang sel-sel normal. Salah satu contoh efek samping kemoterapi yaitu kerusakan sel mukosa saluran cerna yang menyebabkan diare. Hal ini dapat mengakibatkan terjadinya dehidrasi, hipokalemia dan asidosis yang tidak jarang berakhir dengan syok dan kematian. Penelitian ini bertujuan untuk mengetahui gambaran klinis diare pada pasien anak dengan LLA yang menjalani kemoterapi. Jenis penelitian ialah deskriptif retrospektif dengan desain potong lintang yang dilakukan pada 60 data rekam medik pasien anak yang mengidap LLA dengan kemoterapi dan disertai diare di Pusat Pengobatan Kanker Ruang Estella Bagian Ilmu Kesehatan Anak RSUP Prof. Dr. R. D. Kandou pada tahun 2011-2015. Simpulan: Pada penelitian ini hanya sebagian kecil pasien LLA dengan kemoterapi yang mengalami diare. Kejadian diare yang disertai darah dan muntah sangat rendah, sedangkan kejadian diare yang disertai demam hanya terjadi pada sebagian anak.
\end{abstract}

Kata kunci: leukemia limfoblastik akut, kemoterapi, diare

Leukemia atau yang lebih dikenal sebagai kanker darah adalah salah satu jenis penyakit yang sangat berbahaya.Leukemia disebabkan karena meningkatnya jumlah sel darah putih dalam darah atau sumsum tulang.sel-sel darah putih yang sebetulnya tidak normal tersebut menggantikan sel darah yang normal. Ketidaknormalan ini membuat fungsi sel terganggu sehingga penderita leukemia harus segera diobati sebab jika tidak, penderita bisa tidak tertolong. Hal ini disebabkan leukemia 
mampu membunuh penderitanya hanya dalam hitungan minggu atau bahkan hanya dalam beberapa hari. Leukemia tersebut dikenal sebagai leukemia limfoblastik akut (LLA). LLA merupakan salah satu kanker darah yang paling sering terjadi pada anak.Leukemia limfoblastik akut (LLA) merupakan keganasan klonal dari sel-sel prekursor limfoid. Lebih dari $80 \%$ kasus, sel-sel ganas berasal dari limfosit B, dan sisanya merupakan leukemia sel $\mathrm{T} .{ }^{1}$

Salah satu tanda seseorang mengidap leukemia adalah kerap mengalami perdarahan atau luka yang berlebihan.Ciriciri leukemia lainnya adalah saat seseorang mudah terkena infeksi.Hal ini disebabkan karena sel darah putih tidak bisa berfungsi secara normal sehingga infeksi mudah terjadi.pada umumnya penderita leukemia sering terserang infeksi seperti radang amandel, luka di mulut, radang paru-paru, diare, dan berbagai jenis infeksi lainnya., ${ }^{2,3}$

Secara medis, langkah pengobatan leukemia yaitu dengan menggunakan kemoterapi. Kadang juga dilakukan dengan cara radiasi. Tapi umumnya kemoterapi lebih sering dipilih dibandingkan radiasi (penyinaran) untuk mengobati leukemia. Kemoterapi merupakan pengobatan yang menggunakan obat-obat untuk membunuh sel neoplasma.Dilain pihak kemoterapi tidak hanya membunuh sel-sel leukemia tetapi juga menyerang sel-sel normal. Salah satu contoh efek samping kemoterapi ialah kerusakan sel mukosa gastrointestinal yang menyebabkan diare. ${ }^{2}$

Diare menyebabkan tubuh kehilangan air dan garam-garamnya, terutama natrium dan kalium.Hal ini mengakibatkan tubuh mengalami dehidrasi, kekurangan kalium (hipokaliemia) dan asidosis (darah menjadi asam) yang tidak jarang berakhir dengan syok dan kematian. Beberapa penelitian sebelumnya menemukan bahwa penggunaan methotrexate (MTX), hydroxyurea, dan dactinomycin dalam kemoterapi menyebabkan penderita mengalami diare. ${ }^{3}$ Untuk menghindari masalah tersebut diperlukan pengetahuan tentang gejala klinis diare pada pasien anak leukemia limfoblastik akut dengan kemoterapi.
Uraian latar belakang tersebut menjadi dasar penulis untuk melakukan penelitian mengenai gambaran klinis diare pada pasien anak leukemia limfoblastik akut dengan kemoterapi.

\section{METODE PENELITIAN}

Jenis penelitian ini ialah deskriptif retrospektif dengan menggunakan desain potong lintang. Jumlah sampel penelitian sebanyak 17 berkas rekam medik pasien 5 tahun terakhir, dengan teknik pengambilan sampel menggunakan total sampling. Pengumpulan data dilakukan dengan cara memilih data rekam medik pasien anak dengan leukemia limfoblastik akut dari tahun 2010-2015. Berkas rekam medik tersebut dipisahkan antara pasien yang memiliki riwayat diare dan tidak diare, peneliti melakukan penelitian pada berkas rekam medik pasien yang memiliki riwayat diare dengan cara mengamati gejala klinis berupa demam, muntah, konsistensi tinja, warna tinja, dan ada atau tidak ada darah pada feses.

Data diolah dan disajikan berdasarkan distribusi frekuensi dalam bentuk tabel.

\section{HASIL PENELITIAN}

Tabel 1 memperlihatkan distribusi subyek berdasarkan kejadian diare. Karakteristik tinja ditampilkan dalam Tabel 2. Distribusi diare berdasarkan gejala penyerta (demam dan muntah) ditunjukkan dalam Tabel 3 dan 4.

Tabel 1. Distribusi subjek berdasarkan kejadian diare pada pasien LLA

\begin{tabular}{ccc}
\hline Kejadian diare & $\mathrm{n}$ & $\%$ \\
\hline diare & 17 & 28 \\
tidak diare & 43 & 72 \\
total & 60 & 100 \\
\hline
\end{tabular}

Tabel 2. Distribusi gambaran karakteristik tinja berdasarkan ada tidaknya darah

\begin{tabular}{ccc}
\hline Darah & $\mathrm{n}$ & $\%$ \\
\hline ada & 1 & 6 \\
tidak ada & 16 & 94 \\
total & 17 & 100 \\
\hline
\end{tabular}


Tabel 3. Distribusi diare berdasarkan demam

\begin{tabular}{ccc}
\hline Demam & $\mathrm{n}$ & $\%$ \\
\hline ada & 4 & 23,5 \\
tidak ada & 13 & 66,5 \\
total & 17 & 100 \\
\hline
\end{tabular}

Tabel 4. Distribusi diare berdasarkan muntah

\begin{tabular}{ccc}
\hline Muntah & $\mathrm{n}$ & $\%$ \\
\hline ada & 4 & 23,5 \\
tidak ada & 13 & 66,5 \\
total & 17 & 100 \\
\hline
\end{tabular}

\section{BAHASAN}

Leukemia limfoblastik akut merupakan kanker yang paling sering menyerang anakanak dibawah umur 15 tahun, dengan puncak insiden antara umur 3 dan 4 tahun. Di Indonesia 2000-3200 anak terserang LLA setiap tahunnya. Pada penelitian ini yang dilakukan di Pusat Pegobatan kanker ruang Estella Bagian Imu Kesehatan Anak RSUP Prof. Dr. R. D. Kandou Manado terdapat 60 pasien LLA yang mendapat kemoterapi dan 17 pasien LLA yang mengalami diare dalam kurun waktu tahun 2011-2015.

Berdasarkan penelitian didapatkan dari 60 pasien LLA terdapat 17 pasien yang mengalami diare (28\%) sedangkan 43 pasien tidak mengalami diare $(72 \%)$. Penelitian ini menunjukkan bahwa pasien LLA yang tidak mengalami diare lebih banyak daripada pasien yang mengalami diare.

Sesuai dengan literatur yang menjelaskan bahwa salah satu konsekuensi utama dari LLA ialah ketidakmampuan sistem imun mempertahankan tubuh dari invasi benda asing, sehingga mudah mengalami infeksi. Infeksi merupakan komplikasi kemoterapi yang paling sering, dan merupakan penyebab kedua dari seluruh kematian pada anak ALL. Infeksi salah satunya ialah diare. Diare pada anak dengan LLA dapat disebabkan oleh invasi bakteri/virus baik setelah terjadi imunosupresi, maupun akibat dari kemoterapi yang memiliki sifat toksik dan mengganggu sel pada jaringan berproliferasi tinggi yaitu sistem hemopoietik dan terutama sistem gastrointestinal. $^{4,5}$

Dalam penelitian yang dilakukan oleh Hidayat et al. di RSCM, didapatkan bahwa dari 30 orang subjek penelitian terdapat 6 orang yang mengalami diare $(20 \%){ }^{5}$ Hasil ini sejalan dengan hasil penelitian yang dilakukan oleh peneliti di RSUP Prof. Dr. R. D. Kandou Manado.

Berdasarkan hasil penelitian didapatkan bahwa sebanyak 94\% pasien yang diare memiliki tinja yang tidak disertai dengan darah dan $6 \%$ lainnya memiliki tinja yang disertai dengan darah. Dalam literatur diare yang disertai darah dapat menyebabkan anoreksia, penurunan berat badan dengan cepat, dan kemungkinan terjadi komplikasi pada mukosa. ${ }^{4,5}$

Berdasarkan hasil penelitian didapatkan bahwa sebanyak $23,5 \%$ pasien diare yang disertai demam dan $66,5 \%$ pasien diare yang tidak disertai demam. Menurut literatur pada umumnya demam muncul jika penyebab diare mengadakan invasi ke dalam sel epitel usus. Demam juga dapat terjadi karena dehidrasi. Demam yang timbul akibat dehidrasi pada umumnya tidak tinggi dan akan menurun setelah mendapat hidrasi yang cukup. ${ }^{4}$

Berdasarkan hasil penelitian didapatkan bahwa sebanyak 4 pasien LLA dengan diare disertai muntah $(23,5 \%)$ sedangkan pasien LLA dengan diare yang tidak disertai muntah sebanyak 13 anak (76,5\%). Hasil tersebut menunjukkan bahwa pasien LLA dengan diare yang disertai muntah lebih sedikit dibandingkan dengan yang tidak disertai muntah. Penelitian sebelumnya yang dilakukan oleh Dewi et al. di RSUP Sanglah dari 25 sampel didapatkan 6 sampel yang mengalami muntah $(24 \%) ;{ }^{5}$ hal tersebut selaras dengan penelitian yang dilakukan di RSUP Prof. dr. R. D. Kandou.

\section{SIMPULAN}

Dari hasil penelitian terhadap data rekam medik pasien anak penderita leukemia limfoblastik akut yang menjalani kemoterapi dapat disimpulkan bahwa hanya sebagian kecil pasien mengalami 
diare. Kejadian diare yang disertai darah dan muntah pada anak dengan leukemia limfoblastik yang menjalani kemoterapi sangat rendah, sedangkan kejadian diare yang disertai demam hanya terjadi pada sebagian kecil anak.

\section{SARAN}

1. Diharapkan pihak rumah sakit dapat mencari metode pencegahan untuk diare agar tidak terjadi peningkatan kejadian diare pada pasien anak dengan leukemia limfoblastik akut dan menjaga kualitas hidup dari anak-anak yang menderita leukemia.

2. Penelitian ini diharapkan menjadi referensi untuk pihak rumah sakit sebagai salah satu solusi dalam mengatasi masalah diare pada anak dengan leukemia limfoblastik akut dengan kemoterapi. Dan dapat dijadikan acuan untuk penelitian selanjutnya terhadap kasus diare pada anak dengan leukemia limfoblastik akut.

3. Untuk peneliti selanjutnya diharapkan dapat meneliti lebih lanjut lagi mengenai obat yang menyebabkan diare dan cara mengatasi diare pada pasien anak leukemia limfoblastik akut.

4. Diharapkan untuk peneliti selanjutnya dapat menganalisis diare dan gambaran klinis diare pada anak dengan leukemia limfoblastik akut.

\section{DAFTAR PUSTAKA}

1. Setiati S, Idrus A, Aru WS, Marcellus SK, Bambang S, Ari FS. Buku Ajar Ilmu Penyakit Dalam (6th ed). Jakarta: Interna Publishing, 2014; p. 2683-6.

2. Pinontoan E, Mantik M, Rampengan N. Pengaruh kemoterapi terhadap profil hematologi pada penderita leukemia limfoblastik akut. Universitas Sam Ratulangi [serial online] 2013. [cited 2015 Sept 27]. Available from: http://ejournal.unsrat. ac.id/index.php/ eclinic/article/view/3277.

3. Ariawati K, Endang W, Djajadiman G. Toksisitas kemoterapi leukemia limfoblastik akut pada fase induksi dan profilaksis susunan saraf pusat dengan metotreksat 1 gram. Sari Pediatri. 2007;9:254-6.

4. Suraatmaja S. Kapita Selekta Gastroenterologi Anak. Jakarta: Sagung Seto, 2007; p. 1-7.

5. Dewi N, Ariawati K, Niruri R. Efektivitas ondansetron dalam menangani mual dan muntah pasca kemoterapi metotreksat dosis tinggi pada pasien anak dengan leukemia limfoblastik akut. [serial online] 2014. [cited 2016 Feb 5]. Available from: http://ojs.unud.ac.id/index.php/jfu/arti cle/view/13105/8779. 